cells in the epidermis to express the high affinity $\operatorname{IgE}$ receptor ${ }^{17}$ and do so especially in atopic eczema, ${ }^{18}$ in which IgE may play a part in antigen presentation. ${ }^{19}$

These strands of information still have to be woven into a coherent theory, and it remains likely that many genes and environmental factors play a part in the pathogenesis of atopic diseases. Nevertheless, at last a bridge is being built between the immediate hypersensitivity components of atopy, such as asthma and hay fever, and the delayed ones, such as eczema. We must wait for the next instalment of this still shadowy but important story. Meanwhile, the prevalence of atopy continues to rise.

JA SAVIN Consultant dermatologist

Royal Infirmary,

Edinburgh EH3 9YW

\footnotetext{
1 Coca AE, Cooke RA. On the classification of the phenomena of hypersensitiveness. $f$ Immunol 1923;8:163-82.

2 Cookson WOCM, Hopkin JM. Dominant inheritance of atopic immunoglobulin-E responsiveness. Lancet 1988;:86-8.

3 Cookson WOCM, Sharp F, Faux JA, Hopkin JM. Linkage between immunoglobulin-E responses underlying asthma and rhinitis and chromosome 11q. Lancet 1989;i:1292-5.
}

4 Cookson WOCM, Young RP, Sandford AJ, Moffatt MF, Shirakawa T, Sharp PA, et al Maternal inheritance of atopic IgE responsiveness on chromosome 11q. Lancet 1992;340:381-4.

Coleman R, Trembath RC, Harper II. Chromosome $11 \mathrm{q} 13$ and atopy underlying atopic eczema. Lancet 1993;341:1121-2.

6 Hizawa N, Yamaguchi E, Ohe M, Itoh KA, Furuya K, Ohnuma N, et al. Lack of linkage between atopy and locus 11q13. Clin Exp Allergy 1992;22:1065-9.

7 Amelung PJ, Panhuysen CIM, Postma DS, Levitts RC, Koeter GH, Francomano CA, et al. Atopic and bronchial hyperresponsiveness: exclusion of linkage to markers on chromosomes $11 \mathrm{q}$ and $6 \mathrm{p}$. Clin Exp Allergy 1992;22:1077-84.

8 Lympany P, Welsh KI, Cochrane GM, Kemeny DM, Lee TH. Genetic analysis of the linkage between chromosome 11q and atopy. Clin Exp Allergy 1992;222:1085-92.

9 Moffatt MF, Sharp PA, Faux JA, Young RP, Cookson WOCM, Hopkin JM. Factors confounding genetic linkage between atopy and chromosome 11q. Clin Exp Allergy 1992;22:1046-51.

10 Morton NE. Major loci for atopy? Clin Exp Allergy 1992;22:1041-3.

11 Schultz Larsen FS, Holm NV, Henningsen K. Atopic dermatitis. If Am Acad Dermatol 1986;15:487-94.

12 Diepgen TL, Fartasch M. Recent epidemiological and genetic studies in atopic dermatitis. Acta Derm Venereol 1993;suppl 176:13-8.

13 Dold S, Wist M, Von Mutius E, Reitmeir P, Stiepel E. Genetic risk for asthma, allergic rhinitis and atopic dermatitis. Arch Dis Child 1992;67:1018-22.

14 Ruiz RG, Kemeny DM, Price JF. Higher risk of infantile atopic dermatitis from maternal atopy than from paternal atopy. Clin Exp Allergy 1992;22:762-6.

15 Kuster W, Petersen M, Christophers E, Goos M, Sterry W. A family study of atopic dermatitis. Clinical and genetic characteristics of 188 patients and 2151 family members. Arch Dermatol Res 1990;282:98-102.

16 Sandford AJ, Shirakawa T, Moffatt MF, Daniels SE, Ra C, Faux JA, et al. Localization of atopy and beta-subunit of high-affinity IgE receptor (FceRl) on chromosome 11q. Lancet 1993;341: 332-4.

17 Rieger A, Wang B, Kilgus O, Ochiai K, Maurer D, Fodinger D, et al. FceR1 mediates IgE binding to human epidermal Langerhans cells. F Invest Dermatol 1992;9:305-25.

18 Barker JNWN, Alegre CA, MacDonald DM. Surface-bound immunoglobulin-E on antigen presenting cells in cutaneous tissue of atopic dermatitis. I Invest Dermatol 1988;90:117-21.

19 Mudde GC, Van Reijsen FC, Bruijnzeel-Koomen CAFM. IgE-positive Langerhans cells and TH2 allergen specific T cells in atopic dermatitis. F Invest Dermatol 1992;99:1035.

\title{
Deaths from stroke in younger people
}

\author{
Audit can identify the avoidable factors
}

The idea that "avoidable" deaths can be identified to serve as a quantitative negative index of health, reflecting possible deficiencies in the provision of health care, is an appealing concept. As with all such outcome measures, however, attention should be given to potential confounding factors. At best avoidable deaths may serve as a warning signal that all may not be well in the health service. ${ }^{1}$

In the United States the preventable and manageable disease working group devised some quantitative negative indices of health based on unnecessary and early deaths due to conditions in which single occurrences would justify inquiry and on conditions for which increases in rates of disease, disability, or untimely death could serve as indices of the quality of care. ${ }^{2}$ In the United Kingdom and the European Community similar indicators have been developed for 14 conditions in people aged under $65 . .^{3}$

League tables of districts' standardised mortality ratios for these conditions have attracted a lot of interest. The public health common dataset, which contains district and regional standardised mortality ratios for these conditions, ${ }^{4}$ shows substantial differences between and within regions in Britain. ${ }^{34}$ The House of Commons Committee of Public Accounts recommended that the Department of Health should stimulate managers and clinicians to investigate avoidable deaths and remedy any deficiencies. ${ }^{5}$

Local investigation has varied from inactivity through reviews of case notes to confidential inquiries and case control-studies. ${ }^{6}$ The two well established national confidential inquiries into maternal and perinatal deaths and the voluntary inquiry into surgical deaths (CEPOD) are examples of the detailed methods that can be used to investigate such warning signals. ${ }^{78}$ Though there may be little objective evidence to prove that the confidential inquiry into maternal deaths has been an important cause of the pronounced decline in maternal mortality in the past 50 years, it has led to changes in obstetric practice and training. ${ }^{8}$

A reduction in the mortality from stroke in people aged under 75 is a target in the Health of the Nation, and districts with a high standardised mortality ratio for this supposedly avoidable condition should be considering how to achieve it. ${ }^{9}$ Death from hypertensive disease and stroke is considered to be avoidable because hypertension can be both readily detected and effectively treated. ${ }^{139}$ Nevertheless, though hypertension has the highest population attributable risk, it is only one of several eminently treatable risk factors (such as atrial fibrillation) that should be considered in inquiries into deaths from stroke. ${ }^{10}$ And while hypertension can be detected and adequately treated in trials, there are many reasons, such as the willingness of patients to take drugs and the adequacy of treatment and follow up in practice, that may lead to failures.

This week, on $\mathrm{p}$ 1027, Payne et al have drawn on the methods used in the confidential inquiry into perioperative deaths (CEPOD) to investigate deaths from hypertension and stroke in a district health authority. ${ }^{11}$ This may be a somewhat costly and labour intensive means of study, but it is one that could be used by other districts with high standardised mortality ratios for such avoidable deaths. The findings are broadly similar to those of an inquiry in Walsall in the mid-1980s, which more clearly defined the role of the patient and different parts of the service in the deaths. ${ }^{12}$

In the current study only $27 \%$ of deaths were associated with avoidable factors, according to the investigators, but this is not surprising as in only half the deaths from stroke was there definite evidence of hypertension, and avoidability did not relate to other risk factors. Had the inquiry's net been cast wider to incorporate more detailed findings on smoking, atrial fibrillation, alcohol consumption, obesity, and, if relevant, ethnic group, more deficiencies in the provision of health services might have been highlighted.

Investigation of such factors may become more feasible as general practitioners increasingly maintain records of their health promotion activities. The strength of this inquiry, which took account both of avoidable factors and of minimum standards of practice, is that decisions were not made on the basis of avoidability alone. On the other hand, inquiries without control subjects are not able to establish the contribu- 
tion of the avoidable factor to the death; at best they can suggest that it was an associated factor.

Nevertheless the inquiry by Payne and colleagues managed to uncover a number of deaths that might have been prevented given competent practice. It should return to the problem after a year or two to determine whether the number of these sentinel events has fallen.

Inquiry into such events in young people should certainly be encouraged, and mechanisms should be developed to allow the incorporation of audit methods into the contracting process.

CHARLES WOLFE Senior lecturer in public health medicine

Department of Public Health Medicine,

Division of Community Health,

UMDS, St Thomas's Hospital,

London SE1 7EH
1 Chartton JRH, Hartley RM, Silver T, Holland WW. Geographical variation in mortality from conditions amenable to medical intervention in England and Wales. Lancet 1983;i:691-6

Rutstein DD, Berenberg $W$, Chalmers TC, Child CG, Fishman AP, Perrin EB. Measuring the quality of medical care: a clinical method. New Engl f Med 1976;294:548-88.

3 Holland WW, ed. The European Community atlas of "avoidable deaths," Vol II. Oxford: Oxford University Press, 1993. (Commission of the European Communities health services research series 6.)

4 Department of Health. Public health common data set England and Wales 1986-1990 London: DoH, 1991.

5 House of Commons Committee of Public Accounts. Quality of clinical care in National Health Service hospitals (Oth report). London: HMSO, 1989.

6 Wolfe CDA. Avoidable mortality. Foumal of Management in Medicine 1989;4:104-7

7 Buck N, Devlin HB, Lunn HN. The repon of the confidential enquiry into peroperative deaths. London: Nuffield Provincial Hospitals Trust, 1987.

8 Department of Health, Welsh Office, Scottish Home and Health Department, and Department of Health and Social Security, Northern Ireland. Report of confidential enquiries into maternal deaths in the United Kingdom 1985-1987. London: HMSO, 1991.

9 Department of Health. The health of the nation, key area handbook: coronary heart disease and stroke. London: DoH, 1993.

10 Ebrahim S. Clinical epidemiology of stroke. Oxford: Oxford Medical Publications, 1990.

11 Payne JN, Milner PC, Saul C, Bowns IR, Hannay DR, Ramsau LE. A locally-based confidential enquiry into stroke and hypertensive deaths (CESHAD): the methodology and illustrative results from an average sized health district. $B M Y$ 1993;307:1027-30.

12 Singal GM, Stilwell PJ, Chambers J, Clews B. A confidential enquiry into premature preventable deaths. Pilot study. Walsall: Walsall Health Authority, 1985.

\section{A model for British medical education}

\section{The model seems to be agreed: now it needs implementing}

The way medical students are trained has been widely criticised in recent years. Grossly overloaded curriculums, rote learning, the inclusion of topics with little obvious relevance to medical practice, and inappropriate teaching methods have been blamed for stifling enthusiasm, inhibiting students' ability to benefit from postgraduate and continuing training, and even contributing to stress and depression in junior doctors. ${ }^{1}$ The criticisms have come from students themselves, from medical educationalists, and also from staff at some of the world's most prestigious medical schools. ${ }^{23}$

In Britain the General Medical Council, which is ultimately responsible for approving undergraduate education, has been expressing its concerns for decades, ${ }^{4}$ and in May 1991 it issued a discussion document that has since become the focus for wide debate about the problems of medical education in Britain. ${ }^{5}$ In August the council published its revised recommendations on undergraduate medical education, based largely on the responses to its earlier document. ${ }^{6}$ Formal consultations on the draft paper have just closed, and the GMC's education committee is due to report to the full council next month.

The council believes that the recommendations will promote an approach to medical education that will "differ substantially from those of the traditional curriculum." One of the main aims is to reduce the factual overload that has dogged the medical curriculum since at least the last century. As expected, the council has opted for a model with a core set of courses and "special study modules." All students will study core courses for part of the time (the current document does not specify how much, but two thirds of the total time is likely). The rest of their time will be spent on personal in depth study of subjects of their own choosing. (The term "options" used in the discussion document has been dropped, presumably because too many people concluded that these studies would not be compulsory.)

Despite stating that a core curriculum is likely to create "an increased degree of standardisation" the council has so far shown no interest in defining a national core curriculum. This will certainly be criticised in the medical schools' responses. Many schools are unwilling to embark on major reforms of their curriculums in case they "get it wrong" and come up with a core that the General Medical Council declines to approve. Some have even suggested that the council has a statutory obligation under the 1983 Medical Act to define the core. (The act requires the council's education committee to "determine the extent of the knowledge and skill which is required.") An inquiry organised by the King's Fund in 1990 called for a nationally defined core. ${ }^{2}$

Nevertheless, the General Medical Council is likely to resist these calls. Any attempt to define a national core would require an unprecedented amount of time, effort, and money. Those who oppose the idea of a national core also express concerns about the opportunity it would create for outsiders such as governments and managers to influence its content. Some also fear (or hope) that a national core would lead eventually to national licensing examinations.

Everyone agrees, however, that if the council wants schools to adopt the model of a core and modules it must give more guidance about how to implement this. The draft document hopes that "the practice of sharing of ideas and of learning materials... will become a tradition... in order to reduce unnecessary duplication of effort." The least that the council should do is to set up and support an infrastructure that will guarantee that this happens, perhaps by building on the foundation provided by the "change in medical education" network already established by the King's Fund.

Perhaps the bravest and most exciting element of the draft recommendations is the absence of any reference to traditional subjects and disciplines. There is talk of "human biology," "disease processes," and "principles of therapy" but no mention of anatomy, physiology, pathology, or pharmacology. This is combined with a strong emphasis on full vertical and horizontal integration of the courses. The basic and clinical sciences are to be taught together throughout the course, removing the traditional division between preclinical and clinical studies. Inevitably this will be greeted with wails of protest by those who wish to defend their departmental bastions. But the flexibility permitted by this document should provide an opportunity, once and for all, for individual specialties (especially the basic sciences) to prove their relevance and justify their inclusion in the undergraduate course.

Another important innovation is the inclusion of "skills objectives." Students will have to show proficiency in essential 